\section{Ny utgave av godt ettbinds anatomiatlas}

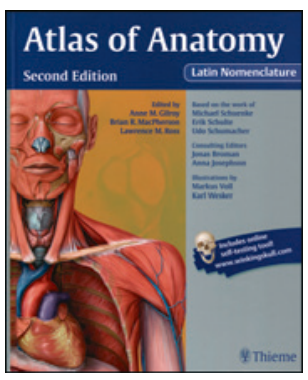

Anne M. Gilroy, Brian R. MacPherson, Lawrence M. Ross, red.

Atlas of anatomy

Latin nomenclature. 2. utg. 712 s, tab, ill. New York, NY: Thieme, 2012. Pris EUR 90 ISBN 978-1-60406-747-7

Jeg anmeldte første utgave av dette atlaset i Tidsskriftet (1) og konkluderte med: «Alt i alt er dette et fremragende atlas, basert på en gjennomtenkt pedagogisk plan og imponerende forståelse av målgruppens behov.»

Målgruppen er fortsatt først og fremst medisin- og fysioterapistudenter, men jeg vil tro at atlaset også dekker behovet for anatomiske tegninger for de fleste leger i ikke-kirurgiske disipliner. Den nye utgaven er moderat utvidet med en del nye, velvalgte figurer. Ellers har den også gjennomgått en viss reorganisering. For eksempel er tegninger som viser overflateanatomien nå plassert først for hver region. En stor fordel for norske brukere er at nomenklaturen nå er gjennomført latinsk. De anatomiske tegningene holder meget høy kvalitet, både estetisk og anatomisk. Små bokser med relevante kliniske poenger finnes strategisk plassert gjennom hele boken.

Med hvert eksemplar av boken følger en kode som gir adgang til nettsiden WinkingSkull.com hvor illustrasjonene finnes elektronisk, og hvor man kan teste seg selv på ulike måter. Det viser seg dessverre at utvalget av tilgjengelige illustrasjoner er tilfeldig og sterkt begrenset - hvis man ikke er villig til å betale rundt 350 kroner $\mathrm{i}$ tillegg, for et halvt års tilgang. Hadde enda de figurene man fikk tilgang til ved å kjøpe boken, vært nøye utvalgt for å dekke det viktigste, kunne det kanskje forsvares, men slik er det ikke. Det virker som om forlaget bevisst vil tvinge brukerne til å betale ekstra.

Til tross for atlasets utvilsomt sterke sider har jeg en mer grunnleggende kritikk. Den er riktignok ikke spesifikk for dette atlaset, men rammer andre atlaser og mange lærebøker: Det mangler helt referanser til vitenskapelig litteratur og andre kunnskapskilder boken er basert på. Det kan kanskje aksepteres når det gjelder de anatomiske tegningene (selv om de også representerer tolkninger og betydelige forenklinger av virkeligheten, og normale variasjoner ikke er tematisert). Men det er mer problematisk når det gjelder de kliniske poengene og de skjematiske lærebokfremstillingene av systemer, som det er en god del av. Her vil det som regel finnes ulike oppfatninger og motstridende observasjoner i litteraturen. Likevel sitter leseren igjen med inntrykket av at alt er sikker og veletablert kunnskap, uten rom for tvil. Jeg tror vi gjør våre studenter en bjørnetjeneste ved å fremstille medisinens kunnskapsgrunnlag på denne måten, selv om det gjøres i beste mening.

\section{Per Brodal}

Institutt for medisinske basalfag

Universitetet i Oslo

Litteratur

1. Brodal P. Ettbinds anatomisk atlas i toppklasse. Tidsskr Nor Legeforen 2009; 129. 129

\section{Innertier om muskel- og skjelettultralyd}

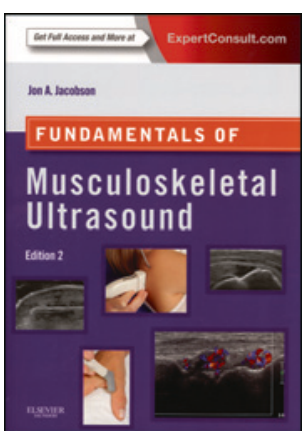

\author{
Jon A. Jacobson \\ Fundamentals of musculoskeletal
} ultrasound

2. utg. 382 s, tab, ill. Philadelphia, PA: Elsevier

Saunders, 2013. Pris EUR 70

ISBN 978-1-4557-3818-2

Muskel- og skjelettultralyd har de siste årene gjennomgått en betydelig videreutvikling. Tekniske nyvinninger har forbedret den diagnostiske kvaliteten og utvidet bruksområdene. Metoden anses i dag som førstevalg i utredningen av en rekke muskel- og skjelettsykdommer.

Seks år etter første utgivelse presenterer Jon A. Jacobson en fornyet utgave av sin lærebok om muskel- og skjelettultralyd. Forfatteren er professor i radiologi og leder for avdelingen for muskel- og skjelettradiologi ved Universitetet i Michigan, USA. Han har stor erfaring fra sitt fagområde, og han deler raust sine kunnskaper med leseren. Boken er rikt illustrert og kan brukes både i opplæringen av nybegynnere og som et oppslagsverk for erfarne ultralydbrukere.

Boken er utgitt som paperback, men kjøperen får også tilgang til den mer omfattende e-versjonen. I papirversjonen er de to første kapitlene Innføring og Basale konsepter av patologi utelatt, og leseren tas direkte til kapitlene som omhandler de forskjellige anatomiske områdene (skulder, albue, håndledd og hånd, hofte og lår, kne, legg, ankel og fot). Hvert kapittel består av en grundig innføring i undersøkelsesteknikk, med presentasjon av standardprojeksjoner, pasientens posisjonering og transducerens plassering. Anatomiske tegninger gjør det lett å forstå hvordan tredimensjonal anatomi fremstilles som tverrsnittsbilde på ultralyd. Deretter følger en gjennomgang av eksempler med vanlige og sjeldne patologiske tilstander. Kvaliteten på og utvalget av bilder er meget bra. Den ledsagende teksten er instruktiv, gir mange gode diagnostiske tips og påpeker vanlige kilder for feiltolkning. Papirversjonen avsluttes med et viktig kapittel om ultralydveiledede intervensjoner og en organspesifikk sjekkliste for ultralydundersøkelse.

E-boken er en betydelig utvidelse av papirversjonen. I tillegg til teksten og bildene får leseren tilgang til et stort antall videosnutter som viser det viktige dynamiske aspektet av diagnostisk ultralyd. «Real time»-presentasjon av ultralydundersøkelse av normale og patologiske strukturer og av intervensjoner gir høy læringseffekt. En liten ulempe er det at litteraturlisten kun foreligger i e-boken, noe som krever at man må være online for å kunne sjekke referanser.

Denne boken er skrevet av en ener i sitt fag, som lykkes i å videreformidle mye av sin erfaring og kunnskap til leseren. Den burde være til stor glede for alle som driver med muskel- og skjelettultralyd i Norge. Boken er kompakt, oversiktlig og kan kjøpes for en gunstig pris. Den får min beste anbefaling.

Stefan Moosmayer

Ortopedisk avdeling

Martina Hansens Hospital 